\title{
ANALISIS KOMPUTASI FLUIDA DINAMIS PADA BANGUNAN PEREDAM ENERGI BENDUNGAN RANDUGUNTING KABUPATEN BLORA PROVINSI JAWA TENGAH
}

\author{
Frika Deddy Sofyan ${ }^{1}$, Very Dermawan ${ }^{2}$, Emma Yuliani $^{2}$ \\ ${ }^{1}$ Staf Dinas Perumahan, Kawasan Permukiman dan Cipta Karya, Bojonegoro, Jawa Timur, Indonesia \\ ${ }^{2}$ Dosen Program Studi Magister Sumber Daya Air, Teknik Pengairan, Fakultas Teknik Universitas Brawijaya, \\ Malang, Jawa Timur, Indonesia \\ Email : frikadesof@gmail.com
}

\begin{abstract}
ABSTRAK Desain bangunan pelimpah Bendungan Randugunting menggunakan model sidechannel spillway (pelimpah samping) dengan tipe ambang pelimpah ogee. Pada uji model fisik, khusus untuk bagian bangunan peredam energi menggunakan sistem kolam olakan datar USBR tipe II termodifikasi dengan panjang kolam olakan $31 \mathrm{~m}$ serta secara teknis direncanakan berdasarkan debit banjir rancangan $\mathrm{Q}_{100}$ dan dikontrol dengan mengalirkan debit banjir $\mathrm{Q}_{1000}$ dan $\mathrm{Q}$ maksimum yang mungkin terjadi $\left(\mathrm{Q}_{\mathrm{PMF}}\right)$. Tujuan penelitian ini untuk mengetahui perilaku aliran hidrolika yang terjadi pada model numerik berbasis CFD di bagian peredam energi dengan variasi panjang kolam olakan $31 \mathrm{~m}, 39 \mathrm{~m}$ dan $53 \mathrm{~m}$, sehingga diperoleh desain bangunan yang optimum ditinjau dari efisiensi peredaman yang terjadi, klasifikasi aliran di escape-channel serta perilaku vektor kecepatan fluida. Dari hasil analisa numerik diketahui bahwa bangunan peredam energi dengan panjang kolam olakan 39 m mempunyai performa efisiensi peredaman yang optimum jika dibandingkan dengan dua model lainnya walaupun sama-sama menghasilkan aliran subkritis di saluran escape-channel, dengan efisiensi peredaman sebesar 56,72\% dan bilangan Froude sebesar 0,14 , sedangkan untuk model dengan panjang kolam olakan $31 \mathrm{~m}$ dan $53 \mathrm{~m}$ berturut-turut efisiensi peredamannya $54,5 \%$ dan $43,26 \%$ serta bilangan Froude 0,15 dan 0,11.
\end{abstract}

Kata Kunci: CFD, Hidrolika, Pelimpah, Peredam energi, Loncatan hidraulik

\begin{abstract}
Spillway construction design of Randugunting dams used side-channel spillway with ogee type. On the physical model test, especially for the stilling basin, using modified of stilling basin USBR Type II with $39 \mathrm{~m}$ length. It is also based on flood discharge design $Q_{100}$ and controlled by flood discharge design $Q_{1000}$ and $Q$ probably maximum flood $\left(Q_{P M F}\right)$. The aim of this study is to describe a detail of numerical model based on CFD about hydraulics patterns of stilling basin basin caused by variation of it longs, that are $31 \mathrm{~m}, 39 \mathrm{~m}$ and $53 \mathrm{~m}$, so that the optimum design can be obtained, in term of the efficiency of energy dissipation, flows classification in the escape-channel and the vector pattern of fluid velocity. From the analysis result obtained that stilling basin with $39 \mathrm{~m}$ length has an optimum performance if compared with the other models although produced the same subcritical flow in the escape-channel, which is the efficiency of energy dissipation is $56.72 \%$ and the Froude number 0.14, while the other models with $31 \mathrm{~m}$ and $53 m$ length has the efficiency of energy dissipation respectively $54,5 \%$ and $43,26 \%$, and the Froude number of 0,15 and 0,11.
\end{abstract}

Keywords: CFD, Hydraulics, Spillway, Stilling Basin, Hydraulics Jump

Kabupaten Blora Provinsi Jawa Tengah merupakan daerah yang relatif kering, dengan sumber air yang relatif sedikit. Dalam rangka pemenuhan kebutuhan air irigasi, air baku, pembangkit tenaga listrik dan pengendalian banjir, maka direncanakan pembangunan Bendungan Randugunting. Penelitian yang dikaji kali ini adalah dengan melakukan uji model hidrolika pada desain bangunan pelimpah samping Bendungan Randugunting menggunakan aplikasi berbasis elemen hingga dan menggunakan persamaan-persamaan fluida yang disebut dengan Computational Fluid Dynamics (CFD). CFD memprediksi 
perilaku dinamik fluida menggunakan perangkat komputer. Desain bangunan pelimpah menggunakan model side-channel spillway (pelimpah samping) dengan tipe ambang pelimpah ogee. Pada uji model fisik, khusus untuk bagian bangunan peredam energi menggunakan sistem kolam olakan datar USBR tipe II termodifikasi dengan panjang kolam olakan $31 \mathrm{~m}$ serta secara teknis direncanakan berdasarkan debit banjir rancangan $\mathrm{Q}_{100}$ dan dikontrol dengan mengalirkan debit banjir $\mathrm{Q}_{1000}$ dan $\mathrm{Q}$ maksimum yang mungkin terjadi ( $\left.\mathrm{Q}_{\mathrm{PMF}}\right)$. enelitian ini menitikberatkan bahasan tentang penentuan panjang kolam olak optimum serta variasi elevasi dasar bangunan kolam olak yang dilakukan dengan pendekatan empiris.

Penelitian ini dimaksudkan untuk mengetahui perilaku aliran di bangunan peredam energi saat kondisi final design ditinjau dari pendekatan dengan CFD dan alternatif yang direkomendasikan agar bangunan peredam energi lebih optimal ditinjau dari efisiensi peredaman yang terjadi, klasifikasi aliran di escape channel serta perilaku vektor kecepatan fluida.
Tujuan yang ingin diperoleh adalah memberikan pemahaman yang lebih rinci berdasarkan model numerik berbasis CFD tentang perilaku hidrolika yang terjadi di bangunan peredam energi (stilling basin), akibat variasi elevasi dasar kolam olak dan panjang kolam olak.

\section{METODOLOGI PENELITIAN Lokasi Penelitian}

Bendungan Randugunting direncanakan terletak di Kabupaten Blora dan Rembang, dengan lokasi rencana as bendung di Kabupaten Blora, Propinsi Jawa Tengah yang berada di daerah hulu Sungai Randugunting, sedangkan ruas sungainya berada di Sungai Banyuasin, Desa Kalinanas, Kecamatan Japah, Kabupaten Blora dengan luas DAS sebesar $17,981 \mathrm{~km} 2$.

\section{Data teknis perencanaan prototipe}

Data teknis perencanaan prototipe model fisik Bendungan Randugunting secara ringkas dapat dilihat pada Tabel 1. data tersebut dipakai untuk membangun model fisik di laboratorium.

Tabel 1. Tabulasi Kondisi Hidrologis Pelimpah Bendungan Randugunting

\begin{tabular}{|c|c|c|c|c|c|c|c|}
\hline No & Keterangan & Satuan & $\mathrm{Q}_{25}$ & $\mathrm{Q}_{50}$ & $\mathrm{Q}_{100}$ & $\mathrm{Q}_{1000}$ & $\mathrm{Q}_{\mathrm{PMF}}$ \\
\hline 1 & Tipe Pelimpah & & \multicolumn{5}{|c|}{ Pelimpah Samping } \\
\hline 2 & Elevasi Ambang & $\mathrm{m}$ & \multicolumn{5}{|l|}{94,2} \\
\hline 3 & Lebar Ambang & $\mathrm{m}$ & \multicolumn{5}{|l|}{20,0} \\
\hline 4 & Tipe Ambang & & \multicolumn{5}{|c|}{ Ogee } \\
\hline 5 & Debit Inflow & $\mathrm{m}^{3} / \mathrm{det}$ & 80,24 & 82,34 & 82,75 & 86,10 & 205,03 \\
\hline 6 & Debit Outflow & $\mathrm{m}^{3} / \mathrm{det}$ & 20,46 & 21,14 & 21,16 & 23,03 & 67,06 \\
\hline 7 & $\begin{array}{l}\text { Elevasi MAW } \\
\text { Maks. }\end{array}$ & $\mathrm{m}$ & 94,87 & 94,88 & 94,88 & 94,91 & 93,60 \\
\hline 8 & $\begin{array}{l}\text { Tinggi air di atas } \\
\text { Ambang }\end{array}$ & $\mathrm{m}$ & 0,60 & 0,61 & 0,61 & 0,65 & 1,33 \\
\hline 9 & Kecepatan masuk & $\mathrm{m}^{3} / \mathrm{det}$ & 0,24 & 0,15 & 0,25 & 0,24 & 0,71 \\
\hline
\end{tabular}




\section{Pengolahan Data}

Pangolahan data pada penelitian ini dilakukan dalam dua tahap, yaitu pengujian model fisik bangunan peredam energi yang menggunakan sistem kolam olakan datar USBR tipe II termodifikasi dengan panjang kolam olakan $31 \mathrm{~m}$ di laboratorium. Data hasil dari pengujian model fisik di bagian hulu bangunan peredam energi atau lebih tepatnya pada saluran peluncur, dipakai sebagai variabel masukan untuk membangun model numerik dalam analisa pendekatan CFD dengan panjang kolam olakan $31 \mathrm{~m}, 39 \mathrm{~m}$ dan $53 \mathrm{~m}$. Pengambilan nilai variasi panjang kolam olakan tersebut karena mempertimbangkan banyak teori penentuan panjang loncatan hidrolik secara empiris yang dipakai dalam perencanaan kolam olakan sebagai berikut:

a. Loncatan Hidrolik

Loncatan hidrolik, pertama kali diselidiki dengan cara percobaan oleh Bidone, sarjana ltalia, pada tahun 1818. Hal tersebut memberikan gegasan pada Bélanger (1828) untuk memecah antara kemiringan landai (subkritis) dengan curam (superkritis). Pengklasifikasian kondisi dari aliran subkritis, aliran kritis dan aliran superkritis didefinisikan oleh bilangan Froude (Hager, 1992):

$$
F_{1}=\frac{V_{1}}{\sqrt{g \cdot D_{1}}}
$$

$$
\text { dengan: }
$$

$\mathrm{F}_{1}=$ bilangan Froude di titik 1;

$\mathrm{V}_{1}=$ kecepatan aliran rata-rata di penampang $(\mathrm{m} / \mathrm{dt})$ di titik 1 ;

$\mathrm{g}=$ percepatan gravitasi $\left(\mathrm{m} / \mathrm{dt}^{2}\right) ;$

$\mathrm{D}_{1}=$ kedalaman hidrolik $(\mathrm{m})$ di titik 1.

b. Panjang loncatan hidrolik

Panjang loncatan hidrolik ( $\mathrm{Lj}$ ) adalah jarak yang dihitung mulai dari permukaan depan loncatan hidrolik sampai dengan suatu titik pada permukaan gulungan ombak yang menuju ke hilir. Beberapa ahli mencoba merumuskan panjang loncatan hidrolik sebagai sebuah persamaan empiris seperti ditunjukkan dalam Tabel 2.

\begin{tabular}{|c|c|c|}
\hline Peneliti & Rumus Empiris & Tahun \\
\hline Riegel dan Beebe & $L_{j} \approx 5\left(D_{2}-D_{1}\right)$ & (1917) \\
\hline Safranez & $L_{j} \approx 5,2 D_{2}$ & (1927) \\
\hline Ludin dan Barnes & $L_{j}=\left(4,5-\frac{V_{1}}{V_{c}}\right) D_{2}$ & (1934) \\
\hline Woycieki & $L_{j}=\left(D_{2}-D_{1}\right)\left(8-0,05 \frac{D_{2}}{D_{1}}\right)$ & (1934) \\
\hline Smetana & $L_{j} \approx 6\left(D_{2}-D_{1}\right)$ & (1934) \\
\hline Douma & $L_{j}=5,2 D_{2}$ & (1934) \\
\hline Aravin & $L_{j} \approx 5,4\left(D_{2}-D_{1}\right)$ & $(1935)$ \\
\hline Kinney & $L_{j}=6,02\left(D_{2}-D_{1}\right)$ & (1935) \\
\hline Page & $L_{j}=5,6 D_{2}$ & (1935) \\
\hline Chertoussov & $L_{j}=10,3 D_{1}\left(F_{1}-1\right)^{0,81}$ & $(1935)$ \\
\hline Bakhmetef, Matzke & $L_{j}=5\left(D_{2}-D_{1}\right)$ & $(1936)$ \\
\hline Ivanchenko & $L_{j}=10,6\left(D_{2}-D_{1}\right)\left(F_{1}^{2}\right)^{-0,185}$ & (1936) \\
\hline Posey & $L_{j} \approx 4,5-7\left(D_{2}-D_{1}\right)$ & (1941) \\
\hline $\mathrm{Wu}$ & $L_{j}=10\left(D_{2}-D_{1}\right) F_{1}^{-0,16}$ & $(1949)$ \\
\hline Hager dkk. & $\frac{L_{j}}{D_{1}}=220 \cdot \operatorname{tgh}\left(\frac{F_{1}-1}{22}\right)$ & (1992) \\
\hline Marques dkk. & $L_{j}=8,5\left(D_{2}-D_{1}\right)$ & (1997) \\
\hline Simões & $\frac{L_{j}}{D_{2}}=\frac{F_{1}^{2}-81,85 F_{1}+61,13}{-0,62-10,17 F_{1}}$ & (2008) \\
\hline Simões dkk. & $L_{j}=9,52\left(D_{2}-D_{1}\right)$ & (2012) \\
\hline
\end{tabular}

Tabel 2. Beberapa persamaan panjang loncatan hidrolik dari peneliti terdahulu.

Sumber: Schulz, 2015.

Hasil pengujian fisik Seri 1/final design untuk $\mathrm{Q}_{100}$ didapatkan besaran nilai: $D_{1}=$ $0,28 \mathrm{~m} ; D_{2}=6,17 \mathrm{~m}$; bilangan Froude di
$D_{1}=6,25$. Dari data-data tersebut, dihitung panjang $L_{\mathrm{j}}$ empiris dari beberapa peneliti terdahulu menggunakan persamaan di 
Tabel 2 dan hasilnya disajikan sebagaimana Tabel 3. Agar bisa diketahui letak sebaran nilai dominan dari variasi teori panjang loncatan hidrolik, maka digambarkan histogramnya, seperti dalam Gambar 1. Melihat histogram tersebut, frekuensi terbesar nilai $L_{\mathrm{j}}$ terletak di antara $33,56 \mathrm{~m}-44,82 \mathrm{~m}$.

Dalam model fisik telah ditetapkan dengan standar USBR II dengan panjang $L_{\mathrm{j}}$ sebesar $31 \mathrm{~m}$, oleh karena itu panjang kolam olakan $31 \mathrm{~m}$ mewakili nilai untuk variasi $22,30 \mathrm{~m}-33,56 \mathrm{~m}$. Sedangkan untuk mewakili nilai varian terpanjang ditentukan sebesar $53 \mathrm{~m}$ karena pertimbangan faktor lokasi bangunan peredam energi yang terbatas. Sehingga penelitian ini akan menggunakan variasi $L_{\mathrm{j}}$ dengan nilai $(31 \mathrm{~m}, 39 \mathrm{~m}, 53 \mathrm{~m})$ untuk dicari efisiensi peredamannya yang optimum.

Tabel 3. Variasi panjang loncatan hidrolik $\left(L_{\mathrm{j}}\right)$ dari peneliti terdahulu

\begin{tabular}{llr} 
No. Peneliti & \multicolumn{2}{c}{$\boldsymbol{L}_{\mathbf{j}}(\mathbf{m})$} \\
\hline 1 Riegel dan Beebe & $(1917)$ & 29,45 \\
2 Safranez & $(1927)$ & 32,08 \\
3 Woycieki & $(1934)$ & $\mathbf{4 0 , 6 3}$ \\
4 Smetana & $(1934)$ & $\mathbf{3 5 , 3 4}$ \\
5 Aravin & $(1935)$ & 31,81 \\
6 Kinney & $(1935)$ & $\mathbf{3 5 , 4 6}$ \\
7 Page & $(1935)$ & $\mathbf{3 4 , 5 5}$ \\
8 Chertoussov & $(1935)$ & 11,05 \\
9 Ivanchenko & $(1935)$ & 31,69 \\
10 Wu & $(1949)$ & $\mathbf{4 3 , 9 3}$ \\
11 Hager dkk. & $(1992)$ & 14,43 \\
12 Marques dkk. & $(1997)$ & 50,07 \\
13 Simões & $(2008)$ & $\mathbf{3 9 , 5 5}$ \\
14 Simões dkk. & $(2012)$ & 56,07 \\
\hline
\end{tabular}

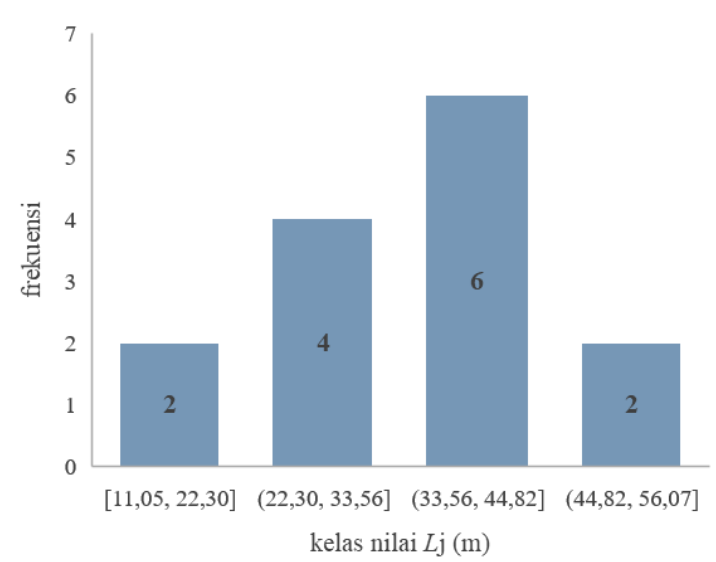

Gambar 1 Histogram nilai $L_{\mathrm{j}}$ dari peneliti terdahulu Sumber: Hasil Perhitungan, 2017

Langkah kerja analisa berdasarkan pendekatan CFD ada tiga tahapan, antara lain:
1. Pre-Processing

Proses yang dilakukan pada langkah ini adalah sebagai berikut: 
a. Membuat geometri model untuk menjadi domain komputasi

Pembuatan geometri model untuk menjadi domain komputasi menggunakan perangkat lunak yang dinamakan FLOW-3D. FLOW-3D adalah perangkat lunak komputasi fluida dinamis umum menggunakan teknik numerik yang dikembangkan secara khusus untuk menyelesaikan persamaan gerak fluida agar diperoleh solusinya dalam tiga dimensi. Gerakan fluida dijelaskan dengan persamaan non-linier, dinamis, diferensial orde kedua. Solusi numerik dari persamaan ini melibatkan pendekatan dari berbagai bentuk ekspresi aljabar. Persamaan yang dihasilkan kemudian diselesaikan dengan proses simulasi untuk menghasilkan solusi pendekatan terhadap masalah asli. Solusi persamaan turbulen yang dapat diaplikasikan dalam perangkat lunak FLOW-3D adalah persamaan k- $\varepsilon$, k$\omega$, RNG (Re-Normalization Group) dan Large Eddy Simulation.

Penggunaan solusi persamaan turbulen RNG mempunyai beberapa kelebihan diban-dingkan dengan persamaan turbulen $k-\varepsilon$ walaupun mempunyai bentuk standar yang serupa, diantaranya (Babaali, 2014):

1. Model RNG mempunyai tambahan bentuk persamaan $\varepsilon$ yang signifikan meningkatkan ri model fisik.. Model pertama dibuat berdasarkan dimensi dan ukuran Seri $\mathrm{E}_{1}-\mathrm{L}_{1}$ dan disajikan dengan dengan akurasi hasil untuk model aliran fluida yang cepat.

2. Peningkatan akurasi hasil untuk efek aliran yang mempunyai banyak pusaran pada pemodelan aliran turbulen RNG.

3. Model fluida dengan bilangan Reynolds yang kecil dan besar dapat diselesaikan dengan model RNG dengan baik, sedangkan model $k-\varepsilon$ hanya berkemampuan baik dalam menyelesaikan model dengan bilangan Reynolds yang besar.

4. Model RNG menyediakan formula analisis untuk menghitung bilangan Prandtl, sedangkan model persamaan standar $k-\varepsilon$ menggunakan nilai yang konstan.

b. Pembuatan mesh dan grid

Model yang akan dibuat sebagai verifikasi model numerik dan model fisik dalam penelitian ini ditunjukkan pada Gambar 2. Gambar ini menunjukkan potongan memanjang bangunan peredam energi yang akan dibuat model numeriknya dilihat dengan titik pandang berasal dari sumbu y negatif antara potongan 14 sampai dengan potongan 25 bangunan pelimpah. Perlakuan model ini termasuk dalam notasi $\mathrm{E}_{1}-\mathrm{L}_{1}$ dimana model ini adalah desain final da

asumsi arah positif sumbu $\mathrm{x}, \mathrm{y}$ dan $\mathrm{z}$ seperti tertuang dalam Gambar 3.

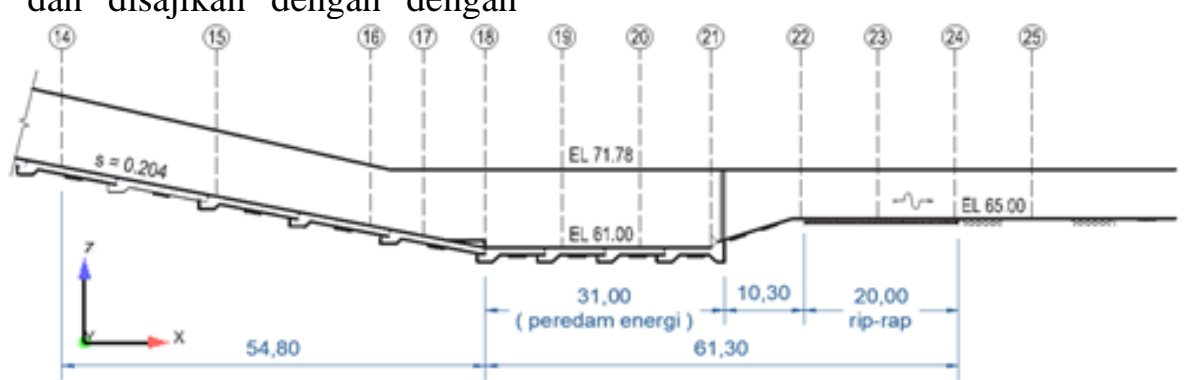

Gambar 2. Potongan memanjang model desain final bangunan peredam energi Sumber: Hasil Perhitungan, 2017

Dapat dijelaskan bahwa saluran masuk (inlet) berada pada nilai $\mathrm{x}$ minimum atau potongan 14 dan saluran keluar (outlet) berada pada posisi nilai $\mathrm{x}$ maksimum atau potongan 24 yang ditandai dengan notasi O. Kondisi batas model pada sumbu $\mathrm{z}$ maximum adalah tekanan udara ditandai dengan notasi huruf $\mathrm{P}$, sedang notasi huruf $\mathrm{W}$ menandakan kondisi batas dinding. 
Arah gravitasi diasumsikan searah dengan sumbu $\mathrm{z}$ negatif.

Semua persamaan yang digunakan untuk memodelkan daerah geometris kompleks diformulasikan dengan fungsi luas dan fungsi porositas volume yang disebut Fractional Area Volume Obstacle Representation $\left(\right.$ FAVOR $^{\mathrm{TM}}$ ) dan secara umum fungsi FAVOR $^{\text {TM }}$ adalah didasarkan waktu independent. Salah satu keunggulan dari aplikasi FLOW-3D dibandingkan dengan aplikasi CFD lainnya adalah kemampuannya untuk mendefinisikan dan membentuk mesh secara baik dari bentuk geometri model dengan penerapan FAVOR ${ }^{\text {TM }}$ (Abrari, 2015). Pembuatan mesh dengan ukuran cell $(0,25 \times 0,25 \times 0,25) \quad \mathrm{m}$ memanfaatkan fasilitas FAVOR dari perangkat lunak FLOW-3D memberikan detail model numerik yang bisa merepresentasikan bangunan peredam energi secara baik karena tidak ada celah kosong dari geometri yang dibuat (Gambar 4).

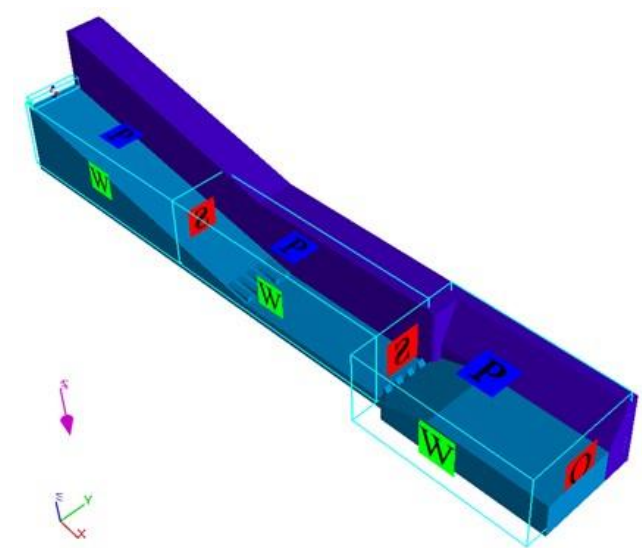

Gambar 3. Model numerik FLOW-3D seri $\mathrm{E}_{\mathbf{1}}-\mathrm{L}_{\mathbf{1}}$ dan kondisi batasnya Sumber: Hasil Perhitungan, 2017

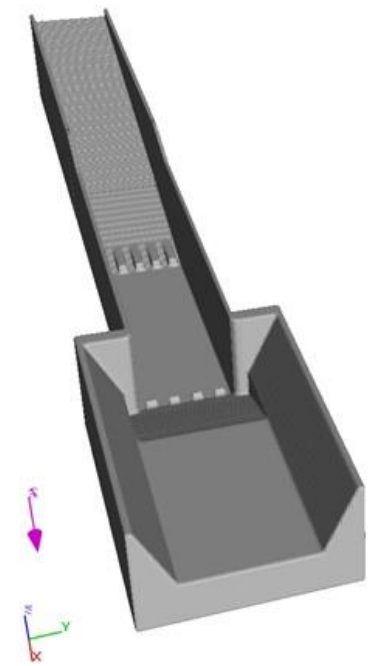

\section{Gambar 4. Hasil mesh FAVOR model numerik Seri E1-L1 \\ Sumber: Hasil Perhitungan, 2017}

c. Mendefinisikan properties fluida dan material kondisi batas lainnya.

Nilai kekasaran permukaan ekuivalen yang diseragamkan biasanya direpresentasikan dengan nilai koefisien Manning. Software Flow-3D memakai nilai tipe kekasaran Nikuradse yang berdimensi panjang, sehingga perlu dikonversikan menggunakan Persamaan (2) Yen, (1991): 
$k_{s}=\left(n \frac{m^{\frac{1}{6}}}{0,0389}\right)^{6}$

dengan:

$n=$ nilai koefisien Manning;

$m=$ bernilai 1 dalam jika satuan

meter.

d. Pengaturan solver (numerical scheme, convergence controls, convergence monitors, dll)

2. Solusi (solver execution)

Pada tahapan ini persamaan-persamaan yang akan digunakan pada simulasi CFD diselesaikan secara iterasi hingga tercapai kondisi konvergen. Tingkat keakuratan solver ditentukan antara lain oleh keakuratan kondisi batas atau asumsi yang dipakai, meshing dan kesalahan numerik (baik karena keterbatasan perangkat lunak maupun karena kekeliruan pengguna perangkat lunak). Persamaan-persamaan tersebut antara lain :

a. Persamaan kontinuitas masa

Secara umum persamaan kontinuitas masa dalam perangkat lunak FLOW3D untuk permasalahan incompressible flow dengan nilai $\rho$ adalah konstan di koordinat cartesian dituliskan sebagai berikut:

$V_{F} \frac{\partial \rho}{\partial t}+\frac{\partial}{\partial x}\left(u A_{x}\right)+\frac{\partial}{\partial y}\left(v A_{y}\right)+\frac{\partial}{\partial z}\left(w A_{z}\right)=\frac{P_{\mathrm{SOR}}}{\rho}(3)$

dengan: $V_{F}$ adalah perbandingan volume terbuka terhadap aliran fluida, $\rho$ berat jenis fluida, $P_{S O R}$ sumber masa. Komponen kecepatan $(u, v, w)$ dalam arah koordinat $(x, y, z) . A_{x}$ menyatakan perbandingan luas terbuka dengan luas teraliri dalam sumbu $x$, begitu pula $A_{y}$ dan $A_{z}$ dalam sumbu $y$ dan $z$.

b. Persamaan Momentum

Persamaan umum gerak fluida untuk komponen kecepatan fluida $(u, v, w)$ pada tiga arah koordinat adalah Persamaan Navier-Stokes dengan beberapa tambahan:

$$
\begin{aligned}
& \frac{\partial u}{\partial t}+\frac{1}{V_{F}}\left(u A_{x} \frac{\partial u}{\partial x}+v A_{y} \frac{\partial u}{\partial y}+w A_{z} \frac{\partial u}{\partial z}\right)=-\frac{1}{\rho} \frac{\partial P}{\partial x}+G_{x}+f_{x} \\
& \frac{\partial v}{\partial t}+\frac{1}{V_{F}}\left(u A_{x} \frac{\partial v}{\partial x}+v A_{y} \frac{\partial v}{\partial y}+w A_{z} \frac{\partial v}{\partial z}\right)=-\frac{1}{\rho} \frac{\partial P}{\partial y}+G_{y}+f_{y} \\
& \frac{\partial w}{\partial t}+\frac{1}{V_{F}}\left(u A_{x} \frac{\partial w}{\partial x}+v A_{y} \frac{\partial w}{\partial y}+w A_{z} \frac{\partial w}{\partial z}\right)=-\frac{1}{\rho} \frac{\partial P}{\partial z}+G_{z}+f_{z}
\end{aligned}
$$

Di dalam Persamaan (4) tersebut variabel $P$ adalah tekanan fluida, sedangkan variabel $\left(G_{x}, G_{y}, G_{z}\right)$ adalah nilai dari body accelerations yang terbentuk akibat percepatan aliran fluida, $\left(f_{x}, f_{y}, f_{z}\right)$ adalah percepatan viscositas.

\section{Post Processor}

Pada langkah ini hasil-hasil komputasi numerik dibuat visualisasi dan didokumentasi. Bila perlu dilakukan pengujian lagi untuk mendapatkan hasil yang lebih akurat sehingga menjawab pertanyaan tentang kesesuaian geometri model, pemenuhan kondisi batas dan kecukupan ukuran mesh.

\section{Analisa Perilaku Hidrolika}

Setelah melakukan simulasi dengan model numerik maka bebarapa analisa perilaku hidrolika akan dipertimbangkan berdasarkan bebarapa teori sebagai berikut:

a. Kehilangan energi

Kehilangan energi pada loncatan mempunyai arti sebagai perbedaan energi spesifik sebelum loncatan dan sesudah terjadi loncatan (Peterka, 1984), besarnya adalah:

jika:

$$
E_{1}=D_{1}+\frac{V_{1}^{2}}{2 g}
$$

dan

$$
E_{2}=D_{2}+\frac{V_{2}^{2}}{2 g}
$$

maka:

$$
E_{L}=E_{1}-E_{2}
$$

dengan:

$$
E_{L}=\begin{aligned}
& \text { kehilangan energi tinggi tekanan } \\
& \text { pada loncatan hidrolik }(\mathrm{m})
\end{aligned}
$$


b. Efisiensi Energi

Efisiensi dari kehilangan energi disusun dengan Persamaan sebagai berikut (Peterka, 1984):

$$
\frac{E_{L}}{E_{1}}=\frac{\left(E_{1}-E_{2}\right)}{E_{1}} \times 100 \%
$$

Besarnya nilai dari Persamaan (3) dalam persentase dipakai untuk menunjukkan seberapa besar kemampuan bangunan peredam energi berfungsi. Semakin besar persentasenya maka hasilnya semakin baik.

c. Loncatan Miring

Saat aliran bergerak miring, lokasi terjadinya loncatan akan bervariasi sesuai dengan debit alirannya, seperti halnya pada arus banjir. Loncatan miring, adalah loncatan dalam saluran dengan kemiringan positif pada bagian hulu dan horizontal pada bagian hilir. Kindsvater (1944) mengklasifikasikan loncatan berdasarkan posisi relatif awal loncatan terhadap tekukan lantai, sebagai berikut (Hager, 1992):

1. Loncatan A, awal loncatan berada di tekukan lantai.

2. Loncatan B, berada diantara loncatan A dan C

3. Loncatan $\mathrm{C}$, putaran terakhir ada di atas tekukan lantai

4. Loncatan D, seluruh putaran berada di bagian aliran miring.

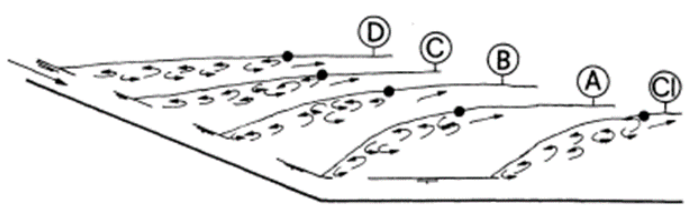

\section{Gambar 5. Tipe aliran loncatan miring} Sumber: Hager, 1992

\section{HASIL DAN PEMBAHASAN}

\section{Hasil Analisa Kecepatan}

Hasil analisa kecepatan dikelompokkan dalam debit, profilnya disajikan dalam Gambar 6. Secara umum efek perubahan panjang kolam olakan dari $31 \mathrm{~m}, 39 \mathrm{~m}$ dan $53 \mathrm{~m}$ membuat kecepatan aliran di bagian saluran escape channel menurun. Untuk debit desain bangunan peredam energi $\mathrm{Q}_{100}$, berturut-turut nilai kecepatan yang didapatkan dari model numerik adalah: 0,697 m/dt; 0,620 m/dt; 0.594 $\mathrm{m} / \mathrm{dt}$. Hal ini membuktikan bahwa dengan menambah pajang kolam olakan mengurangi kecepatan aliran di saluran escape channel.

\section{Hasil Analisa Profil Kedalaman Air.}

Hasil analisa kedalaman aliran dikelompokkan dalam panjang kolam olakan profilnya disajikan dalam Gambar 7 . Perubahan panjang kolam olakan berpengaruh terhadap kedalaman aliran di hilir bangunan peredam energi (saluran escape channel). Panjang kolam olakan dari 31 m, 39 m dan 53 $\mathrm{m}$ membuat kedalaman aliran di bagian saluran escape channel menurun dari 2,247 m ke 2,134 $\mathrm{m}$; dan 2,784 m. Untuk panjang kolam olakan dengan $53 \mathrm{~m}$ nilai yang dihasilkan paling tinggi, hal ini dimungkinkan karena saluran escape channel pada model ini adalah yang terpendek, sehingga dapat diteliti lebih lanjut tentang pengaruh variable panjang saluran escape channel.

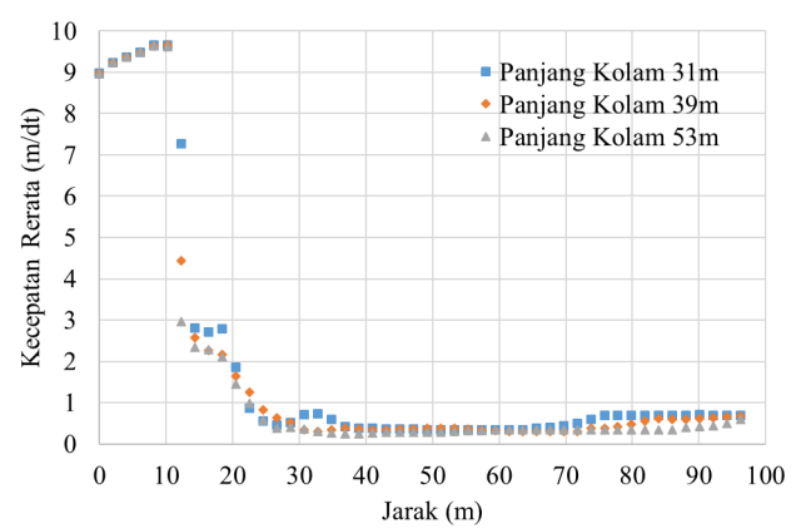

(a)

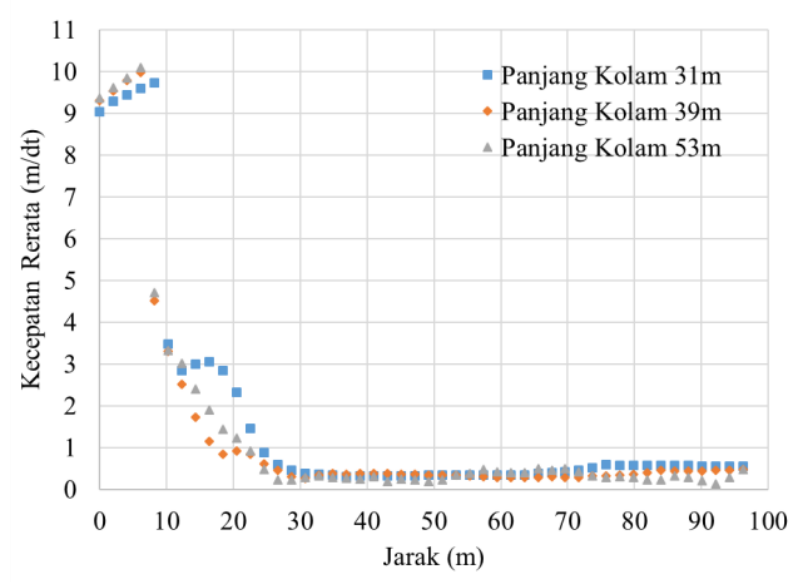

(b) 


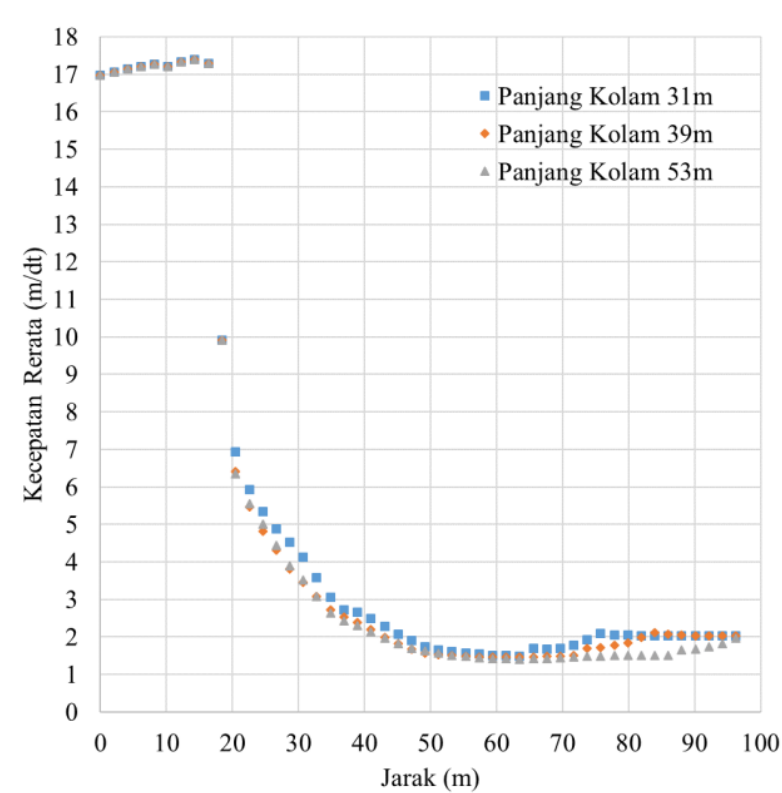

(c)

Gambar 6. Profil Kecepatan (a) $Q_{100}$, (b) $\mathbf{Q}_{1000}$, (c) $\mathbf{Q}_{\mathrm{PMF}}$

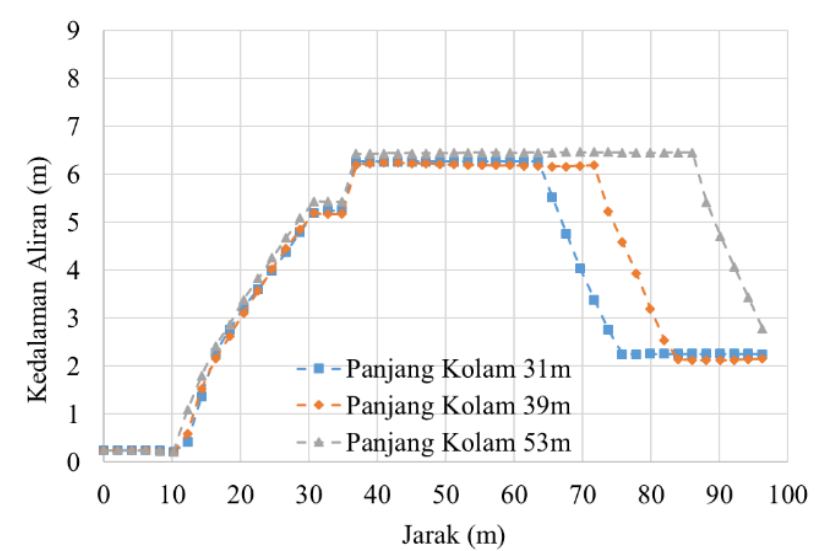

(a)

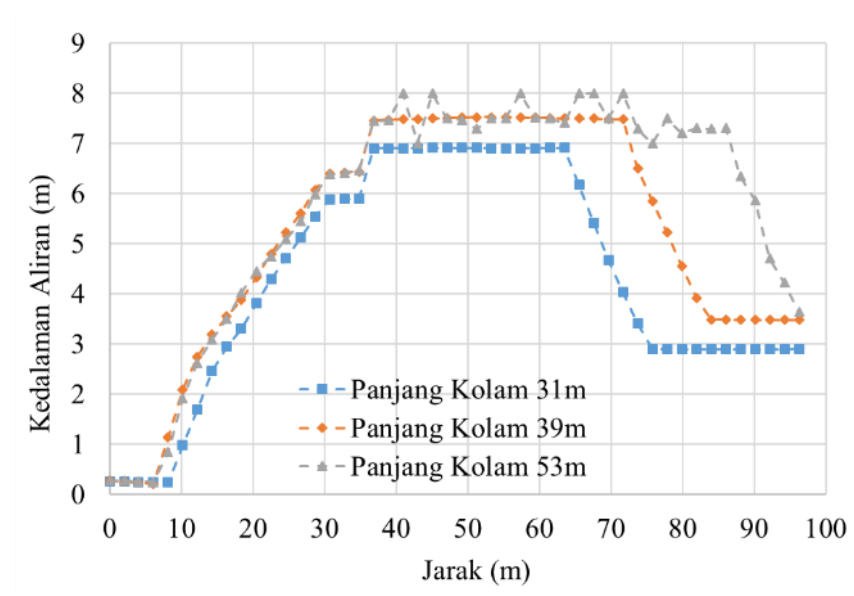

(b)

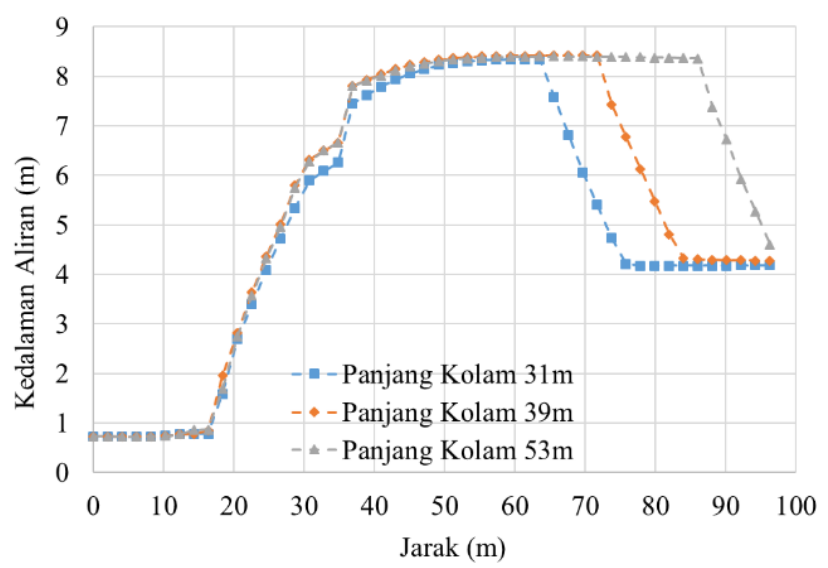

(c)

\section{Gambar 7. Profil Kedalaman Aliran (a) $\mathbf{Q}_{100}$, (b) $\mathbf{Q}_{1000}$, (c) $\mathbf{Q}_{\mathrm{PMF}}$}

\section{Hasil Analisa Bilangan Froude.}

Hasil analisa bilangan Froude (Gambar 8) dikelompokkan dalam panjang kolam olakan. Karena bilangan Froude merupakan fungsi dari kecepatan maka hasil analisanya mempunyai trend yang sama dengan hasil analisa kecepatan. Nilai yang didapatkan adalah: 0,$15 ; 0,14 ; 0,11$ sehingga semua model memberikan hasil subkritis di bagian saluran escape channel. Hasil ini sesuai dengan yang diinginkan untuk sebuah desain bangunan peredam energi.

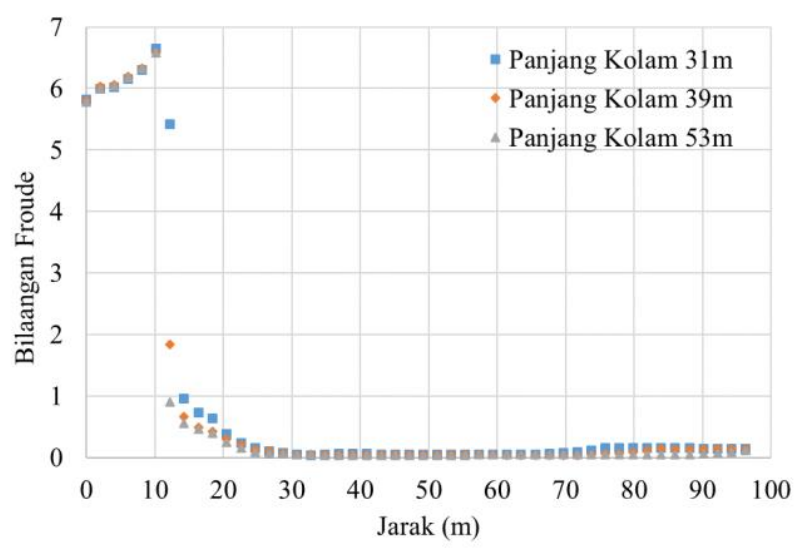

(a) 


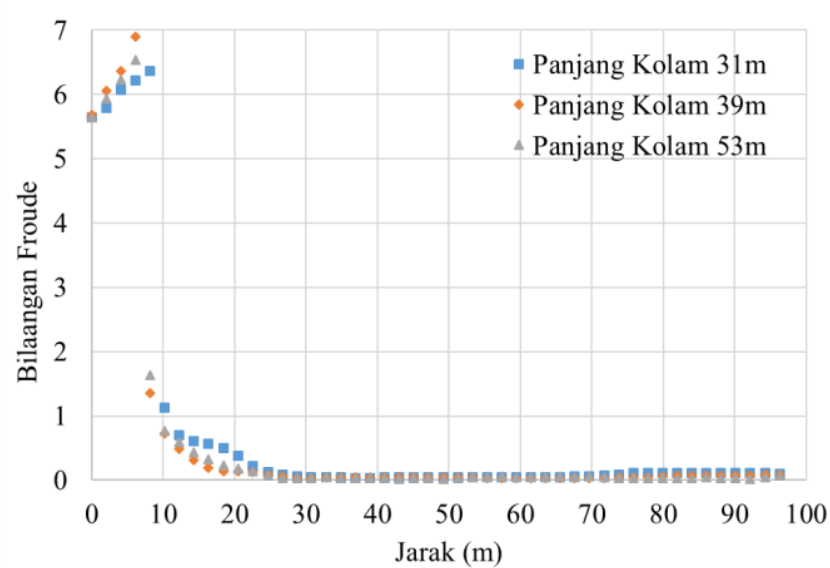

(b)

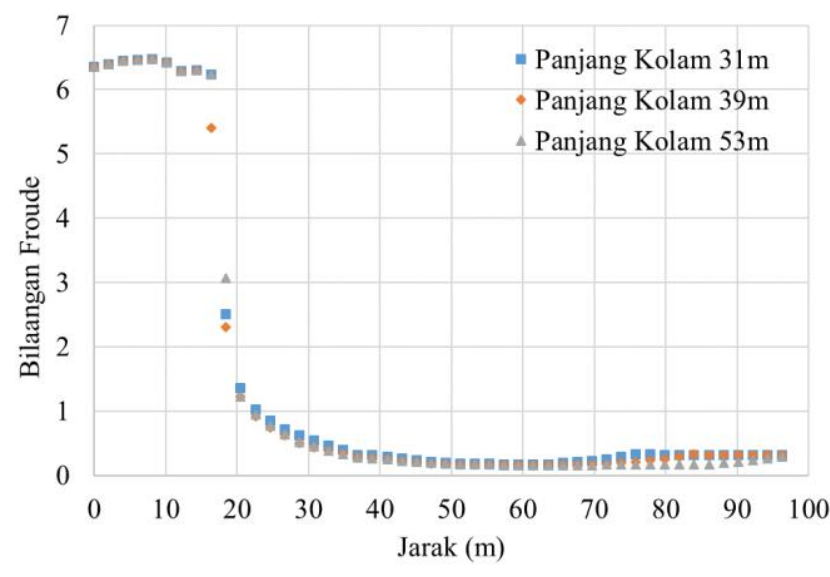

(c)

\section{Gambar 8. Profil Bilangan Froude (a) $\mathbf{Q}_{100}$,} (b) $\mathbf{Q}_{1000}$, (c) $\mathbf{Q}_{\mathrm{PMF}}$

Sesuai dengan beberapa hasil analisa diatas dapat disimpulkan kriteria desain untuk bangunan peredam energi terpenuhi untuk semua model dengan semua variasi debit yang disimulasikan.

\section{Performa Model Peredam Energi}

Perbandingan kehilangan energi akibat loncatan dengan energi awal sebelum mengalami loncatan menggambarkan performa dari peredam energi. Semakin besar nilai prosentasenya maka dapat dikatakan peredaman energi semakin baik. Perhitungan nilai masing-masing prosentasinya berdasarkan perlakuan model dan debit, serta besarnya bilangan Froude yang menggambarkan kategori bentuk aliran di lokasi escape-channel disajikan dalam Tabel 4 dan Gambar 9.

Semua perlakuan model mempunyai aliran subkritis $(F<1)$ di hilir bangunan peredam energi untuk debit rancangan $\mathrm{Q}_{100}$, sehingga dapat dikatakan memenuhi kriteria desain (Tabel 4). Nilai efisiensi tertinggi $56,72 \%$ saat debit $\mathrm{Q}_{100}$ diperoleh saat panjang kolam olakan 39m (Gambar 9).

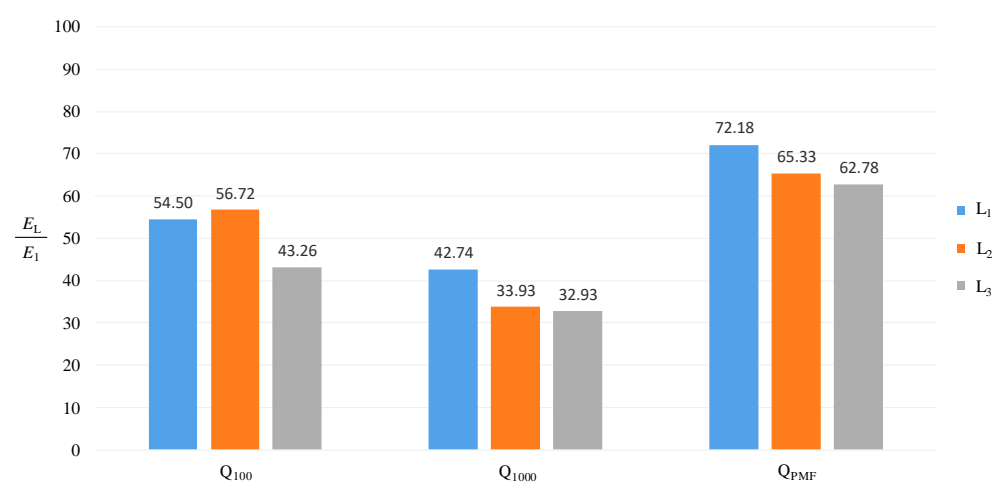

Gambar 9. Grafik $\frac{E_{L}}{E_{1}}$ untuk debit $\mathbf{Q}_{100}, \mathbf{Q}_{1000}$, dan $\mathbf{Q}_{\mathrm{PMF}}$.

Salah satu keuntungan mengunakan model numerik adalah kemampuannya dalam menangkap vektor kecepatan yang terjadi dalam aliran fluida, sehingga perilaku fluida lebih lanjut dapat dipelajari untuk memperoleh desain yang paling optimal dari semua alternatif model. Ilustrasi vektor kecepatan disajikan dalam Gambar 10, 11 dan 12. 

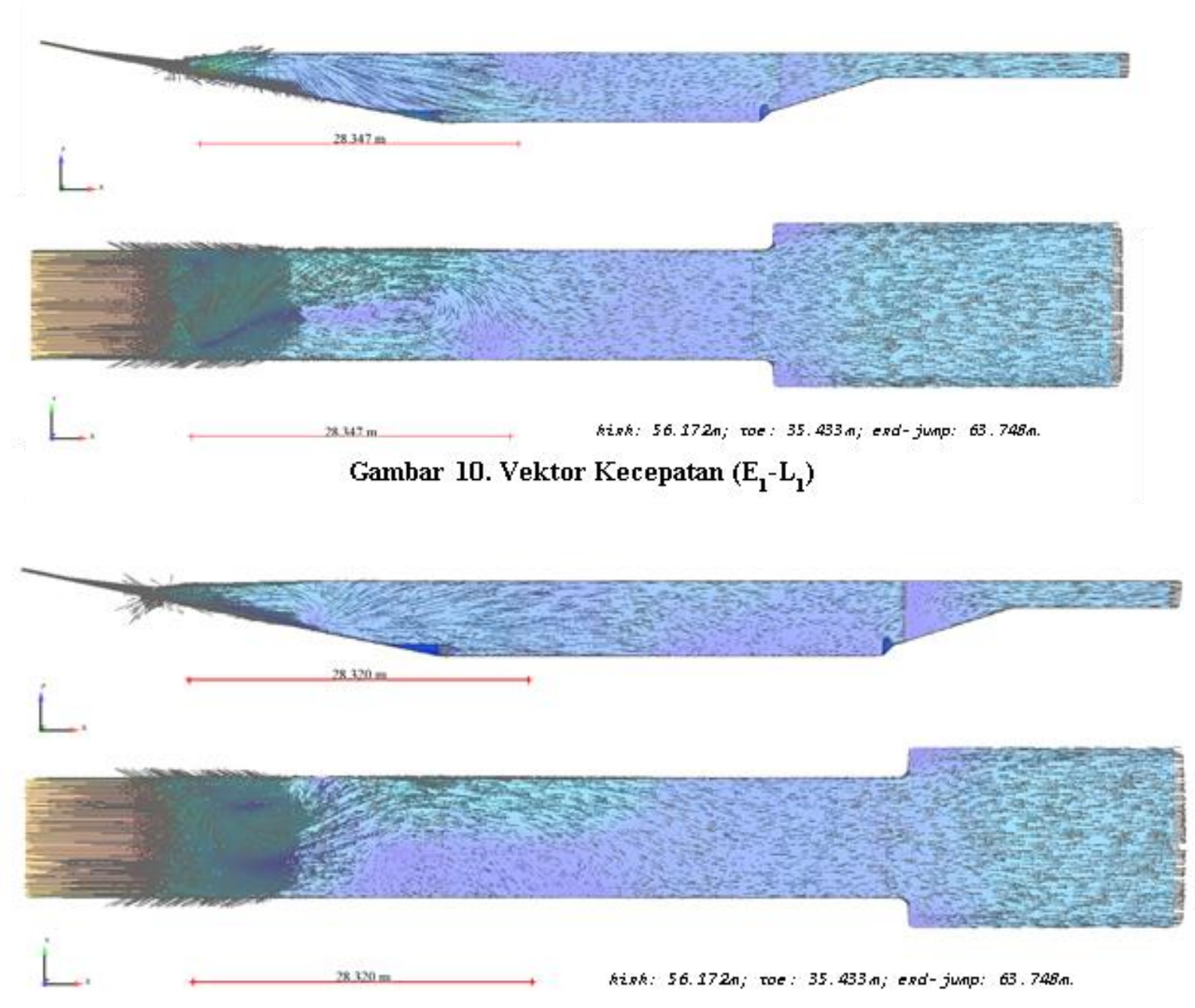

\section{Gambar 11. Vektor Kecepatan $\left(\mathrm{E}_{1}-\mathrm{L}_{2}\right)$}

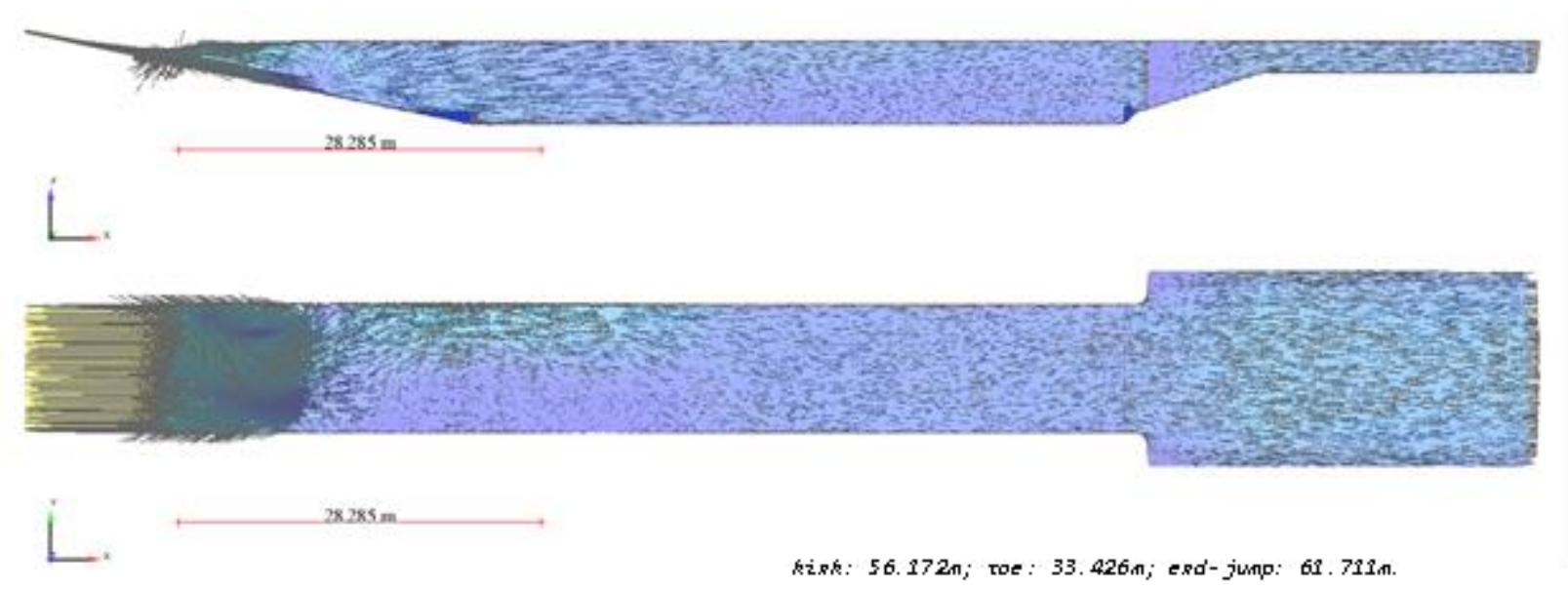

Gambar 12. Vektor Kecepatan $\left(\mathrm{E}_{1}-\mathrm{L}_{3}\right)$ 
Tabel 4. Perbandingan energi yang hilang akibat loncatan dengan energi sebelum loncatan.

\begin{tabular}{|c|c|c|c|c|c|c|c|c|c|}
\hline No. & Notasi & $\begin{array}{c}\text { Debit } \\
\text { Kala } \\
\text { Ulang }\end{array}$ & $\underset{\mathrm{m} / \mathrm{dt}}{Q}$ & $\begin{array}{c}D_{1} \\
\mathrm{~m}\end{array}$ & $\begin{array}{c}D_{2} \\
\mathrm{~m}\end{array}$ & $\begin{array}{c}V_{1} \\
\mathrm{~m} / \mathrm{dt}\end{array}$ & $\begin{array}{c}V_{2} \\
\mathrm{~m} / \mathrm{dt}\end{array}$ & $\begin{array}{l}\frac{E_{L}}{E_{1}} \\
\%\end{array}$ & F \\
\hline \multirow[t]{3}{*}{1} & \multirow{3}{*}{$\begin{array}{l}\text { Model } \\
\text { Fisik }\end{array}$} & $\mathrm{Q}_{100}$ & 21,16 & 0,25 & 2,04 & 10,16 & 0,87 & 62,30 & 0,19 \\
\hline & & $\mathrm{Q}_{1000}$ & 23,03 & 0,44 & 2,77 & 12,59 & 0,87 & 67,04 & 0,17 \\
\hline & & $\mathrm{Q}_{\mathrm{PMF}}$ & 67,06 & 0,73 & 3,87 & 16,34 & 1,74 & 71,94 & 0,28 \\
\hline \multirow[t]{3}{*}{2} & \multirow[t]{3}{*}{ E1-L1 } & $\mathrm{Q}_{100}$ & 21,16 & 0,244 & 2,247 & 9,651 & 0,697 & 54,50 & 0,15 \\
\hline & & $\mathrm{Q}_{1000}$ & 23,03 & 0,262 & 2,899 & 9,734 & 0,586 & 42,74 & 0,11 \\
\hline & & $\mathrm{Q}_{\mathrm{PMF}}$ & 67,06 & 0,729 & 4,209 & 17,266 & 2,088 & 72,18 & 0,32 \\
\hline \multirow[t]{3}{*}{3} & \multirow[t]{3}{*}{ E1-L2 } & $\mathrm{Q}_{100}$ & 21,16 & 0,219 & 2,134 & 9,658 & 0,620 & 56,72 & 0,14 \\
\hline & & $\mathrm{Q}_{1000}$ & 23,03 & 0,213 & 3,485 & 9,978 & 0,452 & 33,93 & 0,08 \\
\hline & & $\mathrm{Q}_{\mathrm{PMF}}$ & 67,06 & 0,842 & 4,333 & 15,542 & 2,119 & 65,33 & 0,33 \\
\hline \multirow[t]{3}{*}{4} & \multirow[t]{3}{*}{ E1-L3 } & $\mathrm{Q}_{100}$ & 21,16 & 0,218 & 2,784 & 9,622 & 0,594 & 43,26 & 0,11 \\
\hline & & $\mathrm{Q}_{1000}$ & 23,03 & 0,243 & 3,632 & 10,088 & 0,471 & 32,93 & 0,07 \\
\hline & & $\mathrm{Q}_{\mathrm{PMF}}$ & 67,06 & 0,861 & 4,606 & 15,373 & 1,972 & 62,78 & 0,29 \\
\hline
\end{tabular}

Sumber: Hasil Perhitungan, 2017.

Vektor kecepatan pada Gambar 10 dengan panjang kolam olakan $31 \mathrm{~m}$ menunjukkan aliran pusaran horisontal yang kuat di lokasi terjadinya loncatan hidrolik. Pola aliran disepanjang kolam olak sedikit menyilang. Panjang loncatan hidrolik adalah 28,315 m dengan tipe locatan hidrolik B.

Vektor kecepatan model dengan panjang kolam olakan $39 \mathrm{~m}$ pada Gambar 11 menunjukkan adanya pola aliran disepanjang kolam olak sedikit menyilang kemudian berpola stabil sampai mencapai saluran escape channel. Panjang loncatan hidrolik yang terjadi 28,320 m dengan tipe locatan hidrolik B.

Pada Gambar 12 model mempunyai Panjang kolam olakan 53 m, vektor kecepatan menggambarkan pola aliran relatif stabil di sepanjang saluran peredam energi sampai saluran escape channel. Panjang loncatan hidrolik yang terjadi $28,285 \mathrm{~m}$ dengan tipe locatan hidrolik B.

\section{KESIMPULAN}

\section{Kesimpulan}

Setelah dilakukan analisa perhitungan dan pengujian pada model fisik bangunan pelimpah dengan skala 1:40 serta dilakukan simulasi dengan model numerik berbasis CFD, maka dapat disimpulkan sebagai berikut :

1. Alternatif desain bangunan peredam energi yang direkomendasikan adalah bangunan peredam energi sistem kolam olakan datar
USBR tipe II termodifikasi dengan panjang kolam olakan $39 \mathrm{~m}$.

2. Penggunaan model numerik berbasis CFD dapat membantu dalam proses optimalisasi desain untuk memangkas biaya dan waktu, dimana hasil analisa panjang kolam olakan $39 \mathrm{~m}$ dapat mengoptimalkan biaya konstruksi untuk bangunan peredam energi karena secara teori nilai panjang loncatan berkisar antara $11,05 \mathrm{~m}$ sampai dengan $56,07 \mathrm{~m}$.

3. Perbandingan energi yang hilang akibat loncatan dengan energi sebelum loncatan saat debit $\mathrm{Q}_{100}$ adalah 56,72\%, debit $\mathrm{Q}_{1000}$ adalah 33,93\% dan debit $\mathrm{Q}_{\mathrm{PMF}}$ adalah 65,33\%. Di saluran escape channel terjadi aliran subkritis dengan bilangan Froude 0,14 untuk debit $\mathrm{Q}_{100} ; 0,08$ untuk debit $\mathrm{Q}_{1000}$ dan 0,33 untuk debit $\mathrm{Q}_{\mathrm{PMF}}$. Loncatan hidrolik yang terjadi adalah tipe $\mathrm{B}$ dengan panjang $28,320 \mathrm{~m}$.

\section{Saran}

Penelitian selanjutnya tentang model numerik turbulen berbasis CFD, disarankan untuk mempelajari secara mendalam tentang penentuan titik awal loncatan hidrolik (toe), titik akhir pusaran aliran (end-roller) yang terjadi, pengaruh udara yang terjebak (air entrapment) dalam aliran serta pengaruh gelembung (bubble). Dikarenakan, sampai saat ini belum ada metode numerik yang pasti 
dalam penentuan variabel-variabel tersebut selain pengamatan visual.

\section{DAFTAR PUSTAKA}

Abrari, L., Talebbeydokhti, N., dan Sahraei, S., 2015, Investigation of Hydraulic Performance of Piano Shaped Weirs Using Three Dimensional Numerical Modeling, Iranian Journal of Science and Technology, Transactions of Civil Engineering Volume 39 Number C2 pp 539-558, Iran: Shiraz University.

Babaali H., Shamsai A., Vosoughifar H., 2014, Computational Modeling of the Hydraulic Jump in the Stilling Basin with Convergence Walls Using CFD Codes, Arabian Journal for Science and Engineering Volume 40, Issue 2, pp 381395, Springerlink.com

Bayon A., Valero D., García-Bartual R., Vallés-Morán F. J., López-Jiménez P.A., 2016, Performance assessment of OpenFOAM and FLOW-3D in the numerical modeling of a low Reynolds number hydraulic jump, Environmental Modelling \& Software Volume $80 \mathrm{pp}$ 332-335, Elsevier Ltd.

Chow, Ven Te. 1992. Hidraulika Saluran Terbuka, terjemahan E.V. Nensi Rosalina. Jakarta: Erlangga.

Hagger, Willi H., 1992, Energy Dissipators And Hydraulic Jump, SpringerScience+Business Media, B.V.

Peterka, A. J., 1984, Hydraulic Design of Stilling Basins and Energy Dissipators, United States Departement of The Interior Bureau of Reclamation.

Schulz, Harry Edmar; Nóbrega, Juliana Dorn; Simões, André Luiz Andrade; Schulz, Henry; and Porto, Rodrigo de Melo., 2015, Hydrodynamics: Concepts and Experiments, Croatia InTech.

Yen, Ben Chie (1991)., Channel flow resistance: centennial of Manning's formula, Water Resources Publications. 